\author{
Sarah SKORBURG, \\ Vijay SHENAI
}

\title{
IMPACT OF NON-PERFORMING LOANS ON SMALLER US BANK PROFITABILITY AND VALUE IN THE POST-CRISIS PERIOD
}

\begin{abstract}
Credit quality is an important constituent of a bank's asset portfolio. Asset quality and inadequate capital reserves were two significant triggers of the Global Financial Crisis (GFC) in 2009. Since then, there has been substantial regulatory and internal risk management changes within the US banking industry. There are no previous specific studies on smaller US banks. This study reviews the empirical literature on the topic of asset quality, bank profitability and market value along with statistics specific to the US banking industry. The impact on profitability is assessed through the return on equity ratio $(\mathrm{ROE})$ and the impact on market value is assessed through the market to book ratio (MTBR). Along with the non-performing loan ratio (NPL), three other CAMEL ratios were also used as independent variables: capital adequacy (TRWCA), liquidity (LIQ) and management efficiency (MAN) to assess their impact on profitability and market value. Panel data has been collected for fifteen smaller US banks and the Generalised Method of Moments (GMM) of estimation is used robustly to estimate the effects of CAMEL ratios on bank profitability and market value. The link between NPL and other ratios on bank profitability and market value in smaller US banks has been assessed. The importance of the NPL ratio for bank profitability and market value is once again confirmed.
\end{abstract}

(C) Sarah Skorburg, Vijay Shenai, 2021.

Skorburg, Sarah, MSc Finance, PhD student, University of Westminster, London. UK. Email: sskorburg@gmail.com.

Shenai, Vijay, PhD, Professor, University of Lincoln, UK. Email: kvshenai11@gmail.com. 


\section{Key words:}

non-performing loans; credit risk; bank-specific factors; dynamic panel.

JEL: G24, C22, C52, C53.

1 figure, 7 tables, 23 references.

\section{Introduction}

The US has approximately 600 publicly listed banks of which 550 are on the NASDAQ stock exchange and the remaining 50 on the NYSE. Within those numbers, there are 5-10 large banks that dominate the US financial services market. Below that, there are numerous smaller banks that are typically more regional in location and range in assets from $\$ 5$ to $\$ 500$ billion. The main financial regulatory body in the US is the Federal Reserve Bank System (Federal Reserve). The structure of the Federal Reserve Bank is shown below.

The Global Financial Crisis in 2009, significantly and forever affected the banking industry within the United States and worldwide. The Federal Reserve was the most aggressive institution in the world in addressing the aftermath of the GFC (Bivens \& Wething, 2013). One of the most significant outcomes of the GFC was new banking regulations (Dodd-Frank Wall Street Reform and Consumer Protection Act) enacted into law in 2010 by the United States government and regulated by the Federal Reserve along with the Basel II and III Accord, aimed at increasing the asset quality of bank loan portfolios and capital adequacy requirements to ensure bank solvency from adverse future events. Prior to the GFC, many banks had increased the risk profile of their loan portfolios and as a result suffered large losses during the GFC and for a couple years afterwards.

Overall, bank profitability determinates are both internal and external in nature. Internal factors include capital adequacy, liquidity and management efficiency ratios along with loan loss reserves (Bourke, 1989). External factors include regulations, competition and interest rates (Bourke, 1989). Within the US, regulations are strict and change in response to political and economic circum- 
stances. The Federal Reserve had significant monetary policy intervention in the US financial markets after the GFC (Gugler \& Peev, 2018). This helped the US banking system to recover from the aftermath of the GFC more quickly than their foreign counterparts and resulted in the ability to return to pre-crisis profitability levels by 2014 (Gugler \& Peev, 2018).

Figure 1

\section{Federal Reserve Bank structure}

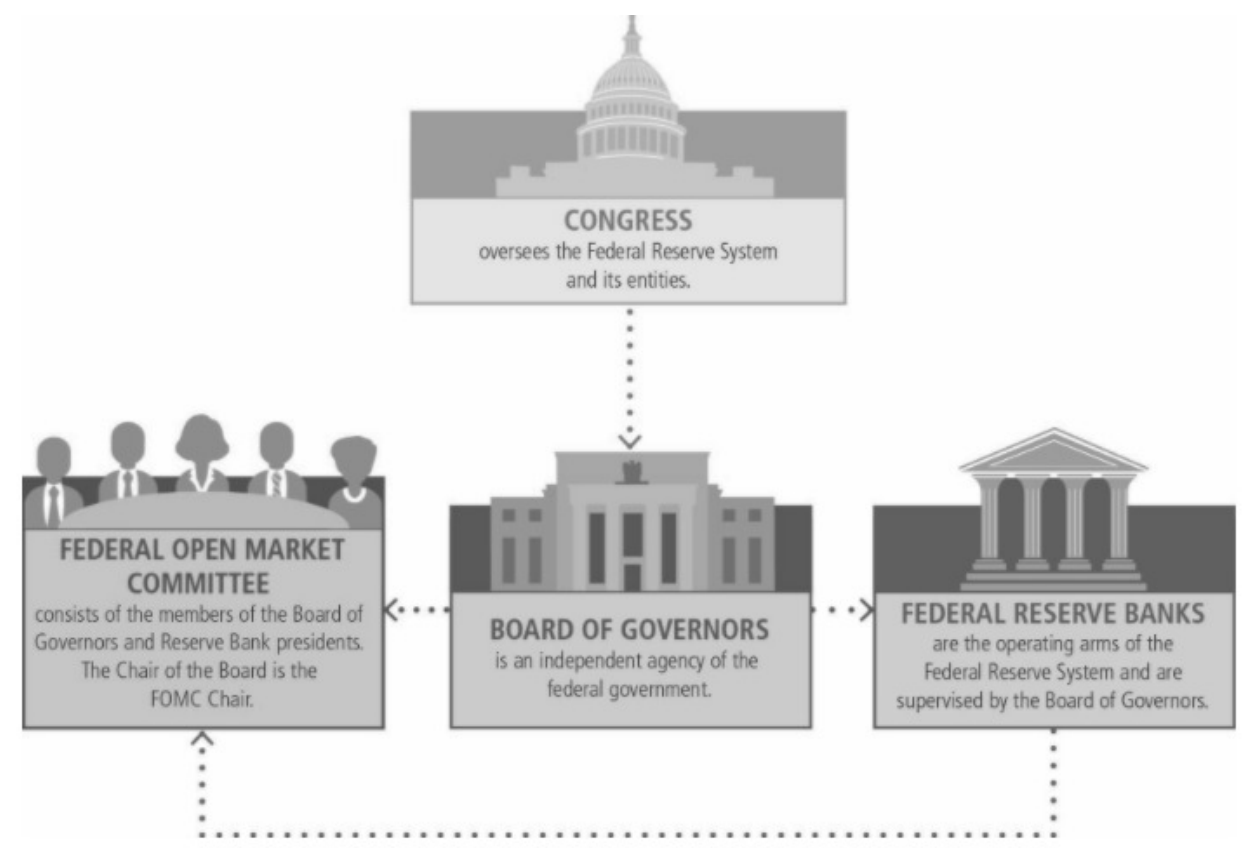

Source: Federal Reserve Board. (n.d.). Structure of the Federal Reserve System. http://www.federalreserve.gov

Typically, the research on determinants of bank profitability in the US has sampled large or top tier banks starting before the financial crisis up to 20142015. There is minimal research available concerning profitability determinates of smaller banks in the USA. With the significant impact of the GFC on the US banking industry, this study explores how asset quality and other banking variables impact the profitability and market value of medium sized US banks. The 
focus will be on non-performing loans and CAMEL ratios. The CAMEL ratio model is a management tool used for evaluating bank performance (Reddy \& Prasad, 2011). CAMEL ratios measure five main components of financial institutions: capital adequacy, asset quality, management efficiency, earnings quality and liquidity (Reddy \& Prasad, 2011). With increased regulatory capital requirements and lower risk lending practices, implemented since 2009, the expectation of this study is that asset quality should improve bank profitability. This will be seen through a reduction in non-performing loans and the provision for loan losses recognized in the income statement along with higher total risk-weighted capital asset ratios.

\section{Literature Review and Problem Statement}

This study aims to research the impact of asset quality on bank profitability and market value. The impact of other variables such as capital adequacy, liquidity and management efficiency will also be assessed given the smaller size of these institutions. This research will contribute to the current literature by sampling 15 smaller banks publicly traded in the USA, which is a sample that has not been as extensively reviewed as top tier banks. Bank profitability will be measured using the Return on Equity (ROE) ratio and Market value will be studied through the Market to Book Ratio (MTBR).

«Smaller» means middle level banks in the United States, which are mostly operating in their own and neighbouring states and not internationally, with assets typically below US $\$ 500$ billion. The larger US banks with assets more than US $\$ 1$ trillion (e.g. JP Morgan, Bank of America, Wells Fargo, CitiGroup) are excluded from the study because they also operate internationally and consequently the characteristics of their assets and investments will be different from those operating substantially in the US. Studies on smaller US banks, which capture what is happening in the US are not seen.

The sample timeframe is the post-crisis period (2010-2018), looking at data entirely after the financial crisis to see what impact asset quality is having on bank profitability and market value.

Bank profitability and market value are of interest to all participants in the stock market. Asset quality is an important constituent in banks' balance sheets. In currently available literature, smaller US banks have not been separately researched. This research will thus fill a gap. The current research intends to estimate the relationship between bank profitability and asset quality, whilst also examining other CAMEL ratio variables and thereafter the link with market value.

Since the global financial crisis in 2009, there has been significant literature produced addressing the impact of credit risk on bank profitability, with par- 
ticular focus on asset quality, which is considered a significant factor in determining the financial health of banking institutions (Saeed \& Zahid, 2016). A study by Saeed and Zahid sampled 5 large UK commercial banks for the period 20072015 and looked at how non-performing loans and impairment charges impacted ROE and ROA, measures of bank profitability (2016). Their results did not find any significant correlation between bank profitability measures and the credit risk variables tested (Saeed \& Zahid, 2016). Another study by Liu, Wu, Lin and Lu (2017) sampled 286 leading banks in Taiwan for the period of 2004-2014. They found that banks that had implemented financial controls over non-performing loans outperformed other banks (Liu et al., 2017). A further study by Ishak, Ismail, Razali, Baker and Ramlan (2016) sampled 3 out of the top 5 banks in Malaysia for the period of 1998-2015. Their results found that ROE is impacted by credit risk indicators and that banks can improve financial performance by implementing credit risk management strategies (Ishak et al., 2016). Overall, research studies have found that credit risk management improves financial performance (Saeed \& Zahid, 2016; Liu et al., 2017; Ishak et al., 2016).

One of the main functions of a bank is to act as a financial intermediary between depositors and lenders. As a result, bank profitability is heavily dependent on the interest rate spread (net interest margin) between lending and depositing as well as the asset quality of the loans originated. Typically, riskier loans carry higher interest rates along with a higher provision for default than high quality loans. A study by Kasavica and Jovic (2015) examined whether banks with a risky loan portfolio specifically selected higher interest rates on those loans to achieve a higher net interest margin and compensate for the loan portfolio risk. The study found that net interest margin does reflect a premium to compensate for the risk of loan default (Kasavica \& Jovic, 2015). In addition, the study showed that large banks had higher sensitivity to the risk of default than smaller banks (Kasavica \& Jovic, 2015).

Bank profitability has many determinants including capital structure, bank size, liquidity, credit risk and asset growth, including investment diversification and loans (Chronopoulous et al., 2015). NPL are considered one of the main drivers of credit risk, and thus profitability, as loan loss reserves are recognized directly in the income statement. This is especially true during economic downturns when the allowance for loan losses typically fall short of actual losses (Bolt et al., 2012). A study by Tran, Lin and Nguyen (2016), found that banks with higher risk of illiquidity, due to NPL, have lower profitability and increased risk of bankruptcy. As asset quality is one of the main drivers of bank profitability, numerous studies have found that poor asset quality is one of the main drivers of bank insolvency (Saeed \& Zahid, 2016). An efficient financial system is assumed to be profitable, with increasing levels of funds moving from depositor to borrower (Hoffman, 2011). The "efficiency-risk hypothesis» states that banks with the highest rates of return will have low capital ratios, indicating higher lending activities and thus higher profitability (Hoffman, 2011). A higher capital ratio may indicate that banks are operating cautiously and thus not operating at full lending ca- 
pacity, which limits profitability (Hoffman, 2011). In addition, increased regulation in the form of higher capital requirements can significantly impact profitability (Hoffmann, 2011).

The literature analysing bank size and profitability is mixed. Conventional wisdom states that larger banks should have higher profitability due to economies of scale and the ability to provide services at a lower cost (Terraza, 2015). A study of 1270 European banks found that credit risk was negatively related to profitability for large banks but not for medium or smaller banks (Terraza, 2015). The study found a positive relationship between credit risk and profitability in smaller European banks (Terraza, 2015).

Credit risk is defined as the risk that the borrower will not be able to repay a loan according to the terms of the loan agreement (Kasavica \& Jovic, 2015). In the USA, regulators are increasingly concerned with bank performance and are requiring higher liquidity and capital requirements to reduce credit risk and adhere to Basel III requirements (Ali \& Puah, 2019). Credit risk is typically measured by the ratio of NPL to total loans or assets and the ratio of the allowance for loan losses (ALL) to total loans. The "skimping hypothesis", proposed in 1997, asserts that credit risk has a negative impact on profitability due to banks focusing on long-term profits over short-term and thus reduce NLP and ALL to achieve cost efficiencies (Ali \& Puah, 2019). In addition, banks with low credit risk tend to have greater consumer confidence and thus can offer lower interest rates on deposits and obtain reduced financing interest rates, which increases profitability (Ali \& Puah, 2019). More recent studies conducted in 2013 and 2015, based on the «risk-return hypothesis», state that credit risk has a positive impact on bank profitability. A higher loan-to-asset ratio results in higher credit risk and also higher interest rates on loans which increases profitability (Ali \& Puah, 2019). Moreover, a higher loan-to-asset ratio can lead to an increase in NPL, indicating a deterioration in a bank's Balance Sheet resulting in an increase in credit risk (Ghosh, 2017).

Since the financial crisis, many banks have reduced their loan risk appetites due to higher credit risk resulting from deterioration of its past loan portfolio (Cucinelli, 2015). The levels of NPL are dependent on both internal and external factors, including credit risk management policies and bank size, along with economic factors like GDP, unemployment and inflation (Kasavica \& Jovic, 2015). The Federal Reserve of the United States of America in its Supervision and Regulation Report - November 2018 (Board of Governors of the Federal Reserve System, 2019), defined NPL as «loans that are 90 days or more past due, plus loans in non-accrual status» (p. 44) and ALL as "a valuation reserve established and maintained by charges against the bank's operating income. As a valuation reserve, it is an estimate of uncollectible amounts that is used to reduce the book value of loans to the amount that is expected to be collected» (p.44). NPL and ALL are both balance sheet items for a bank but also have an impact on operating income and thus profitability. Performing loans become non- 
performing when the risk of default increases due to unemployment, inflation and income levels (Ghosh, 2017). The ALL represents current costs recognized in operating income due to new loans and also deterioration of the existing loan portfolio (Kasavica \& Jovic, 2015). A study of the determinates of ALL, showed that banks who reserved less for loan losses during good economic times had to significantly adjust their allowance, and record higher expense in the income statement for the additional provision during economic downturns (Cucinelli, 2015). The financial impact of an adjustment in the loan loss provision is lower in countries that have higher regulation and accounting disclosures (Cucinelli, 2015). Applying prudent practices, such as establishing an adequate loan loss provision, may reduce profitability in the short term but should improve profitability overall (Bouzgarrou et al., 2018). There is research that has also found the opposite result: that asset quality has a significant negative impact on bank profitability (Bouzgarrou et al., 2018). These studies assert that higher loan loss provisions result in higher bank profitability due to increased interest revenue earned from increased lending at higher risk (Bouzgarrou et al., 2015). Another study found that an increase in NPL results in an increase in costs to manage those loans along with credit supply restraints which reduces a bank's ability to originate new loans, which in turn reduces profitability (Ghosh, 2017). Overall, current literature is mixed on the impact of asset quality on bank profitability.

In the USA, the asset quality of loans is high overall in the banking industry with equity to asset ratios well above the required minimum and low net charge offs to total loans ratio, $0.73 \%$, as reported in a study by Chronopoulous, Liu, McMillian and Wilson in 2015. This study also found a positive relationship between the net charge off to total loans ratio and bank profitability, indicating that a higher quality loan portfolio leads to greater profitability (Chronopoulous et al., 2015). Non-performing loans peaked at approximately 5.5\% in the USA in 2009 leading up to the Global Financial Crisis (GFC) and have steadily declined to under $2 \%$ since that time, suggesting an overall decrease in credit risk of US banks (Ghosh, 2017). As of November 2018, the Federal Reserve Bank stated that the U.S. banking system is financially strong, with profitability as measured by ROE and ROA, reaching a 10-year high in 2018. In this same 10-year period, the Federal Reserve Bank reported that NPL were near a 10-year low, based on the non-performing loan ratio (2018). According to the Federal Reserve Bank, the largest improvement in non-performing loans has been within the largest tier banks (2018).

Since the GFC, one of the biggest impacts on US banking regulations has been the Basel II and Basel III revised standards on the calculation of capital requirements for credit risk. In particular, the revised standards improved the capital requirements calculation of risk-weighted assets (RWA) to make the calculation more credible and comparable amongst banks and put limits on the use of internal bank models. This was done in hopes of increasing bank liquidity buffers as well as consumer confidence in bank reported RWA calculations, as the ratio of RWA to total assets is a common bank comparison measure of capital ade- 

profitability and value in the post-crisis period

quacy and credit risk. Since the revised capital framework of the Basel II accord was not published until mid-2004, not all US banks had implemented the expanded minimum capital requirements, supervisory or disclosure requirements as of the 2009 GFC. Basel III post-crisis reform standards were released in 2017.

The Basel Committee on Banking Supervision (BCBS) was formed in 1974 by $\mathrm{G} 10$ countries to review and make policy recommendations in times of financial stress in the banking system. In summary, the BCBS has come up with three accords to date in response to various crises: the first Accord (Basel I) was finalized in 1988 and it recommended that banks have a minimum capital requirement of $8 \%$ in relation to risk-weighted assets. Following a failure of the banking system in 1997, a second Accord (Basel II) was finalized in 1998; which had three pillars i.e. minimum capital requirements, prudential supervision and market discipline. However, it was clear that these measures were insufficient to cope with the crisis of 2008 and problems of inadequate capital reserves and liquidity came into focus because of defects in the internal credit risk rating models and inability of the banks to cope with market wide shocks. So a third Accord, Basel III, was formulated in 2009 toward ensuring that financial institutions possess suitable reserves to conserve capital, curb excess credit growth and also have sufficient liquidity to meet obligations in difficult market conditions.

This study focuses on publically listed medium sized banks in the US and the impact of NPL as well as CAMEL ratios on profitability. It will contribute to the current literature by sampling a tier of banks that has not been extensively studied and analyse bank data since the GFC period (2010) to current time (2018). Typically, the research on this topic has focused on the largest banks within a given country and it is difficult to find any US bank profitability studies that specifically target smaller banks. Because this tier of US banks has not been extensively studied, not as much is known about the asset quality of their loan portfolios and overall Balance Sheets. This study aims to fill this gap in the research by examining how sensitive smaller bank profitability is to asset quality, since the GFC. Also, with the Basel III post-crisis reform standards just issued in 2017, the more current time frame of the data used will help to determine what impact increased capital requirements is having on bank profitability and if it is in line with regulatory expectations.

\section{Research Design and Data}

While there are different traditions in research, e. g. positivism, interpretivism, deductive and inductive, for this study, the deductive style of research was chosen as there is a body of literature on bank performance. In addition, this study is based on observable and measurable facts, which can be analysed and reviewed. Data is accessed from several banks over numerous years. Such data is classified as panel data. 


\section{Methodology}

The aim of this research is to ascertain the impact of bank specific variables, particularly those related to non-performing loans on bank performance (ROE) and market value (MTBR) in smaller US banks, an area which has not so far been studied. Taking a sample of fifteen banks over the nine years since the GFC (2010-2018), relevant variables are identified from the literature review conducted earlier. The dependent and independent variables chosen are presented in Table 1 below, along with explanations on how the variables are calculated and the expected impact on profitability.

Table 1

\section{Research data variables}

\begin{tabular}{|l|l|l|}
\hline \multicolumn{1}{|c|}{ Dependent Variables } & \multicolumn{1}{c|}{ Formula } & \multicolumn{1}{c|}{ Source } \\
\hline ROE & Net income/Shareholders equity & Bloomberg \\
\hline MTBR & $\begin{array}{l}\text { Market Price per Share/Book Value } \\
\text { per Share (Market to Book ratio) }\end{array}$ & Bloomberg \\
\hline Independent Variables & \multicolumn{1}{|c|}{} \\
\hline NPL & Non-performing loans/Total loans & Bloomberg \\
\hline LIQ & $\begin{array}{l}\text { Cash+Cash Equivalents+Short-Term } \\
\text { Investments/Total Assets }\end{array}$ & Bloomberg \\
\hline TRWCA & Total Risk Based Capital Ratio & Bloomberg \\
\hline MAN & Operating Expenses/Total Assets & Bloomberg \\
\hline LSIZE* & Natural Log total assets & Bloomberg \\
\hline
\end{tabular}

Note*: The size variable is logged to reduce the variations in the data.

Table 1 presents the dependent and independent variables to be used. Return on equity (ROE) and market to book ratio (MTBR) are the dependent variables to measure profitability and market value. The independent variables are NPL (non-performing loan ratio), LIQ (liquidity ratio), TRWCA (risk based capital ratio, MAN (expense ratio) and LSIZE (measure of size). These relate to CAMEL ratios impacting asset quality and bank performance (Reddy \& Prasad, 2011). ROE is calculated by dividing net income by total shareholder's equity. ROE is a good measure of book profitability as it measures the ability of banks to generate revenue based on equity capital raised (Saeed \& Zahid, 2015). MTBR measures market value relative to book value and is calculated by dividing mar- 

profitability and value in the post-crisis period

ket value per share by book value per share. MTBR is a common measure of market value ratio used for banks.

Regression models are estimated consisting of two equations where the relationship of ROE is first tested against independent variables: NPL, TRWCA, MAN and LSIZE. Next, the relationship between MTBR and NPL, TRWCA, LIQ and LSIZE is estimated. These formulations are in line with Basel III.

A panel data approach will be followed to analyse the data, as it is most suitable for a sample that includes both cross-sectional and time-series data (Hoffman, 2011). The Generalised Method of Moments (GMM) is an estimation method to overcome endogeneity problems. Dynamic panel estimation has one or more lagged dependent variables. When $\mathrm{N}$ is larger than $\mathrm{T}$, the Generalised Method of Moments (GMM) using the Arellano Bond method (1991) gives consistent estimators. The moment conditions use the properties of instruments to be uncorrelated with future errors. Data is transformed and an instrument-weighting matrix is used in the estimations. The Arellano Bond serial correlation test is applied on the residuals and the Sargan test for overidentifying restrictions is applied to test the validity of instrumental variables.

NPL is defined based on the US GAAP definition of $90+$ days past due, restructured or non-accrual status. The NPL variable measures asset quality within the CAMEL model. Bank size is important as it considers total loans as well as the investment activities of the bank. Bank size is assumed to have a positive and significant impact on net profit margin (Bouzgarrou et al., 2018). The total risk-weighted assets capital ratio (TRWCA) calculation was introduced as part of the Basel II accords and has been further revised in the Basel III requirements to add credibility to the calculation and improve comparability (Bank for International Settlements). LIQ, MAN and LTDR represent CAMEL model ratios measuring a banks liquidity, management efficiency and capital adequacy, respectively. The CAMEL ratio model is used by regulatory banking authorities to evaluate a bank's performance by measuring Capital Adequacy, Asset Quality, Management Efficiency, Earnings Quality and Liquidity (Reddy \& Prasad, 2011).

The functional forms to be tested are:

$\mathrm{ROE}=f(\mathrm{NPL}, \mathrm{LIQ}, \mathrm{TRWCA}, \mathrm{MAN}, \mathrm{LSIZE})$

MTBR $=f(N P L, L I Q, T R W C A$, LSIZE $)$

Estimations will be accepted after diagnostic tests are performed. 


\section{Data}

The quantitative annual financial data for this study was obtained from company published annual audited financial statements and accessed via Bloomberg, with a data sample of 15 publicly traded smaller banks in the USA over the 9-year post Global Financial Crisis period (2010 to 2018). Overall, 135 observations were collected for each variable tested. These are summarised in Appendix 1. Table 2 presents market information on the 15 smaller banks in the sample, along with the total assets of each bank as a measure of bank size as of December 31, 2018.

Table 2

\section{Bank Sample data}

\begin{tabular}{|l|c|c|c|}
\hline \multicolumn{1}{|c|}{ Bank Name } & $\begin{array}{c}\text { Ticker } \\
\text { Symbol }\end{array}$ & $\begin{array}{c}\text { Stock } \\
\text { Exchange }\end{array}$ & $\begin{array}{c}\text { Bank Size *in millions } \\
\text { (Total Assets 12-31-2018) }\end{array}$ \\
\hline BB\&T Corporation & BBT & NYSE & $\$ 225,697$ \\
\hline BOK Financial Corp & BOKF & NASDAQ & $\$ 38,021$ \\
\hline East West Bancorp & EWBC & NASDAQ & $\$ 41,042$ \\
\hline Fifth Third Bancorp & FITB & NASDAQ & $\$ 146,069$ \\
\hline First Horizon National Corp & FHN & NYSE & $\$ 40,832$ \\
\hline First Midwest Bancorp Inc & FMBI & NASDAQ & $\$ 12,165$ \\
\hline First Republic Bank & FRC & NYSE & $\$ 99,205$ \\
\hline Fulton Financial Corp & FULT & NASDAQ & $\$ 20,682$ \\
\hline PNC Financial Services Group & PNC & NYSE & $\$ 382,315$ \\
\hline SunTrust Banks Inc. & STI & NYSE & $\$ 215,543$ \\
\hline Synovus Financial Corp & SNV & NYSE & $\$ 32,669$ \\
\hline UMB Financial Corp & UMB & NASDAQ & $\$ 23,351$ \\
\hline U.S. Bancorp & USB & NYSE & $\$ 467,374$ \\
\hline Webster Financial Corp & WBS & NYSE & $\$ 27,610$ \\
\hline Washington Trust Bancorp & WASH & NASDAQ & $\$ 5,011$ \\
\hline
\end{tabular}

Note: compiled by the authors using the data of (Bloomberg, 2019). 


\section{Research Results}

\section{Descriptive statistics}

Table 3 below provides selected descriptive statistics of the dependent and independent variables used in the two regression models tested using EViews.

\section{Table 3}

\section{Research data descriptive statistics}

\begin{tabular}{|l|c|c|c|c|c|}
\hline $\begin{array}{c}\text { Dependent } \\
\text { Variables }\end{array}$ & Mean & Median & $\begin{array}{c}\text { Standard } \\
\text { Dev }\end{array}$ & Maximum & Minimum \\
\hline ROE (ratio) & 0.091949 & 0.096200 & 0.063730 & 0.343500 & -0.425900 \\
\hline MTBR (ratio) & 1.425111 & 1.350000 & 0.414369 & 2.460000 & 0.480000 \\
\hline $\begin{array}{c}\text { Independent } \\
\text { Variables }\end{array}$ & & & & & \\
\hline NPL (ratio) & 0.011387 & 0.008000 & 0.001000 & .078000 & .001000 \\
\hline LIQ (ratio) & 0.194523 & 0.177365 & 0.092907 & 0.513224 & 0.045442 \\
\hline TRWCA (ratio) & 0.138844 & 0.136500 & 0.014943 & 0.186500 & 0.110200 \\
\hline MAN (ratio) & 0.029867 & 0.028300 & 0.008130 & 0.054618 & 0.016720 \\
\hline SIZE (natural log size) & 10.67888 & 10.26788 & 1.359927 & 13.05489 & 7.975737 \\
\hline
\end{tabular}

Source: EViews data file.

Based on the descriptive statistics shown in Table 3 above, the mean ROE for the sample was approximately $9.2 \%$, with maximum ROE reported in the sample data of $34.35 \%$, and a minimum ROE of $-42.59 \%$. The minimum ROE was reported by Synovus Financial Corporation (SNV) in 2010, the year directly following the GFC in 2009 and the max ROE was also reported by Synovus Financial Corporation (SNV) in 2012. Within the banking sector, an ROE range between $15-30 \%$ is considered good (Saeed \& Zahid, 2015).

MTBR is the other dependent variable used in this study representing the market view of profitability. The mean MTBR of the sample was 1.425. Typically, MTBR values of 1-3 are considered good value stocks. Given the smaller size of 
banks in this study, the mean MTBR of the data seems reasonable. The maximum MTBR (2.46) in the data sample was seen in 2016 by First Republic Bank (FRC) and the minimum (0.48) by SunTrust Banks Inc. (STI) in 2011.

Turning the focus onto the independent variables used, the descriptive statistics for the main independent variable that represent asset quality, NPL, the data shows a mean of $1.14 \%$ for NPL. The maximum NPL ratio is $7.8 \%$ by SNV in 2011. The minimum NPL is $0.1 \%$ at FRC in 2016, which corresponds to the sample data of MTBR maximum value of 2.46 by FRC in 2016.

Over the time period of 2010 to 2018 , for the MAN ratio the mean of the sample data was $2.99 \%$, meaning that operating expenses represented approximately $3 \%$ of total assets. The maximum MAN ratio was $5.46 \%$ by First Horizon National Corp (FHN) in 2012 and the minimum value was $1.67 \%$ by East West Bancorp (EWBC) in 2015. For the TRWCA ratio, the mean of the sample data was $13.88 \%$. The maximum TRWCA ratio was $18.65 \%$ for First Horizon National Corp (FHN) in 2010 and the minimum value was $11.02 \%$ for First Midwest Bancorp Inc (FMBI) in 2015. For the LIQ ratio, the mean of the sample data was $19.45 \%$. The maximum LIQ ratio was $51.32 \%$ for UMB Financial Corporation (UMB) in 2012 and the minimum value was $4.54 \%$ for Federal Republic bank (FRC) in 2012. LSIZE represents the natural log of total assets, with total assets being the measure of bank size. The sample of fifteen banks are all considered smaller banks in the USA, with total assets between $\$ 5$ and $\$ 500$ billion. The mean bank size of the sample is 10.68 , with a maximum value of 13.05 and a minimum value of 7.98. The biggest bank in the sample as of December 31, 2018 is U.S. Bancorp (USB) with $\$ 467$ billion in total assets and the smallest bank in the sample is Washington Trust Bancorp (WASH) with $\$ 5$ billion in total assets. This range in bank size allows the study to analyse how bank size within this tier of banks impacts profitability in smaller US banks.

\section{Econometric estimations}

\section{Dependent variable ROE}

The estimated results for ROE, using a dynamic panel model are as given in Table 4 and Table 5 below. 
Table 4

Summary of dynamic panel model estimated for ROE

Dependent Variable: ROE

Method: Panel Generalized Method of Moments

Transformation: First Differences

Sample (adjusted): 20142018

Periods included: 5

Cross-sections included: 15

Total panel (balanced) observations: 75

White period instrument weighting matrix

White period standard errors \& covariance (d.f. corrected)

Instrument specification: @DYN(ROE,-2)

Constant added to instrument list

\begin{tabular}{lllll}
\hline \hline Variable & Coefficient & Std. Error & t-Statistic & Prob. \\
\hline \hline ROE(-1) & -0.305366 & 0.134879 & -2.263997 & 0.0268 \\
ROE(-2) & -0.182907 & 0.055493 & -3.296003 & 0.0016 \\
ROE(-3) & -0.169888 & 0.048358 & -3.513128 & 0.0008 \\
LIQ & 0.426134 & 0.137583 & 3.097278 & 0.0029 \\
NPL & -7.371151 & 0.677179 & -10.88509 & 0.0000 \\
TRWCA & 1.353856 & 0.283461 & 4.776162 & 0.0000 \\
MAN & -0.989977 & 0.827854 & -1.195836 & 0.2360 \\
LSIZE & 0.002441 & 0.016155 & 0.151101 & 0.8803 \\
\hline \hline & Effects Specification & & \\
\hline \hline Cross-section fixed (first differences) & & \\
\hline \hline Root MSE & 0.021620 & Mean dependent var & 0.005901 \\
S.D. dependent var & 0.023957 & S.E. of regression & 0.022875 \\
Sum squared resid & 0.035057 & J-statistic & 7.271856 \\
Instrument rank & 15 & Prob(J-statistic) & 0.401134 \\
\hline \hline
\end{tabular}


Table 5

AB Serial Correlation test for ROE estimation in Table 4

Arellano-Bond Serial Correlation Test

Equation: Untitled

Sample: 20102018

Included observations: 75

\begin{tabular}{lllll}
\hline \hline Test order & m-Statistic & rho & SE(rho) & Prob. \\
\hline \hline $\operatorname{AR}(2)$ & 0.125244 & 0.000838 & 0.006693 & 0.9003 \\
\hline \hline
\end{tabular}

The equation is well specified with an acceptable value for the $\mathrm{J}$ statistic, showing that the instrumental variable is uncorrelated to some set of residuals and the acceptance of the null of no second order serial correlation in the residuals through the Arellano-Bond Serial Correlation Test.

The above estimation shows that profitability (ROE) is positively and significantly linked to liquidity and risk weighted capital ratio and significantly and negatively linked to non-performing loan ratio, while the coefficient of management efficiency is negative but insignificant and the coefficient of size is positive but insignificant. This shows the smaller US banks manage their non-performing loans low, maintaining larger risk weighted capital ratios and higher liquidity.

\section{Dependent variable MTBR}

Testing for the relationship between risk weighted capital ratio, liquidity and non-performing loan ratio and size on the market to book ratio, yields the following results, given in Table 6 and 7. 
Table 6

\section{Summary of dynamic panel model estimated for MTBR}

Dependent Variable: MTBR

Method: Panel Generalized Method of Moments

Transformation: First Differences

Sample (adjusted): 20132018

Periods included: 6

Cross-sections included: 15

Total panel (balanced) observations: 90

White period instrument weighting matrix

White period standard errors \& covariance (d.f. corrected)

Instrument specification: @DYN(MTBR,-2)

Constant added to instrument list

\begin{tabular}{lcccl}
\hline \hline Variable & Coefficient & Std. Error & t-Statistic & Prob. \\
\hline \hline MTBR(-1) & -0.715134 & 0.133754 & -5.346633 & 0.0000 \\
MTBR(-2) & -0.901882 & 0.094686 & -9.524965 & 0.0000 \\
LIQ & -1.542232 & 0.914350 & -1.686696 & 0.0954 \\
TRWCA & -6.695661 & 4.630318 & -1.446048 & 0.1519 \\
NPL & -29.09474 & 8.620353 & -3.375122 & 0.0011 \\
LSIZE & 2.124044 & 0.354025 & 5.999693 & 0.0000 \\
\hline \hline \multicolumn{5}{c}{} \\
\hline \hline Cross-section fixed (first differences) & \\
\hline \hline & Root MSE & 0.300686 & Mean dependent var & 0.032333 \\
S.D. dependent var & 0.340099 & S.E. of regression & 0.311240 \\
Sum squared resid & 8.137109 & J-statistic & 9.398522 \\
Instrument rank & 15 & Prob(J-statistic) & 0.401329 \\
\hline \hline
\end{tabular}


Table 7

AB Serial Correlation test for MTBR estimation in Table 6

Arellano-Bond Serial Correlation Test

Equation: Untitled

Sample: 20102018

Included observations: 90

\begin{tabular}{lllll}
\hline \hline Test order & m-Statistic & rho & SE(rho) & Prob. \\
\hline \hline $\mathrm{AR}(2)$ & 0.611528 & 0.431782 & 0.706070 & 0.5409 \\
\hline \hline
\end{tabular}

The equation is well specified with an acceptable value for the $\mathrm{J}$ statistic showing that the instrumental variable is uncorrelated to some set of residuals and the acceptance of the null of no second order serial correlation in the residuals through the Arellano-Bond Serial Correlation Test.

The above relationship shows that the market to book ratio is influenced significantly by important banking variables: liquidity, non-performing loan ratio and size. This means the market penalises the share price for higher values in LIQ and NPL in US smaller banks, but rewards larger banks, expecting economies of scale. The sign of the coefficient of the risk weighted capital ratio is negative but it is insignificant. Intuitively, this does make sense: higher capital ratio means capital servicing charges will be higher; higher non-performing loans mean bank is riskier and higher liquidity means productivity of assets is lowered, while larger size suggests economies of scale.

\section{Conclusions}

This research has provided a critical summary of prior literature related to asset quality and bank profitability along with an overview of the data collection and research methodology and design used. Overall, this study aimed to discover how sensitive smaller bank profitability is to asset quality given the smaller size of these institutions.

The findings from the two regression models show that non-performing loans (NPL) have a significant and negative impact on bank profitability and market value as evidenced by its effect on ROE and MTBR. Banks with higher asset quality loan portfolios, risk weighted capital, and liquidity have higher accounting 

profitability and value in the post-crisis period

profitability; however, the market has a different view on capital ratios and liquidity and size. Based on this, smaller US banks need to focus on lending practices to ensure that they are making high quality loans and properly managing the nonperforming loans within their portfolios as this reflects into the market.

The CAMEL ratios for capital adequacy (TRWCA) and liquidity (LIQ) were found to have a significant impact on ROE or MTBR, but their effect was opposite. As expected, Total Risk Weighted Capital Asset ratio (TRWCA) was found to have a significant impact on bank profitability. However, this is not surprising as equity capital is more costly to service than other forms of finance and higher liquidity implies lower productivity on asset utilisation.

Bank size (LSIZE) and management efficiency (MAN) were two other independent variables examined for their impact on profitability in this research. Intuitively, it might be expected that larger banks would have economies of scale and lower management efficiency would reflect into higher profitability (ROE). However, although the signs of the coefficients of LSIZE and ROE were as expected, the coefficients were not significant on profitability. On market values, the coefficient of LSIZE was significant indicating that the market rewards expected economies of scale. This has an implication for the smaller US banking industry; banks considering increasing in size through mergers, acquisitions or opening additional branches should keep this in mind.

Overall, the results of this study prove that stricter regulations imposed by regulators after the GFC, specifically related to the asset quality of bank loan portfolios, have resulted in greater profitability for banks since 2009. By maintaining a higher quality loan portfolio banks are actually more profitable as well as more financially responsible in lending practices. These regulations are in actuality helping banks to be better managed as well as more profitable and guard against another GFC. Smaller US banks should be embracing the regulatory changes since the GFC and learn from past mistakes to ensure that they stay solvent and never again need government intervention based on poor lending and management practices exhibited prior to the GFC. The Basel Accords too have contributed to improving the safety of banking operations with the latest accent being on higher capital ratios and sufficient liquidity to meet contingencies. Ultimately, financial institutions in the US needs to conduct horizon scanning risk management procedures in order to evaluate likely future developments within the current banking environment that could lead to a reoccurrence of another GFC.

This study was based on nine years of data of fifteen smaller banks in the US after the GFC, out of a total of approximately six hundred publicly listed banks. The sample used is a representative of smaller banks in the US and spans a range of bank size within that band, from $\$ 5-\$ 500$ billion and an extended study could be conducted to include banks of all size. 
ISSN 2519-4070

Appendix 1

Data on smaller US banks

\begin{tabular}{|c|c|c|c|c|c|c|c|c|}
\hline Bank & Year & ROE & MTBR & NPL & SIZE & TRWCA & LIQ & MAN \\
\hline \multirow[t]{9}{*}{ BBT } & 2010 & 0.05 & 1.11 & 0.025 & $157,081.00$ & 0.1550 & 0.1607 & 0.0361 \\
\hline & 2011 & 0.08 & 1.01 & 0.017 & $174,579.00$ & 0.1570 & 0.1399 & 0.0332 \\
\hline & 2012 & 0.11 & 1.07 & 0.012 & $184,499.00$ & 0.1340 & 0.1537 & 0.0316 \\
\hline & 2013 & 0.08 & 1.31 & 0.008 & $183,010.00$ & 0.1430 & 0.1337 & 0.0319 \\
\hline & 2014 & 0.10 & 1.30 & 0.005 & $186,834.00$ & 0.1490 & 0.1227 & 0.0313 \\
\hline & 2015 & 0.08 & 1.20 & 0.004 & $209,947.00$ & 0.1430 & 0.1328 & 0.0298 \\
\hline & 2016 & 0.09 & 1.42 & 0.005 & $219,276.00$ & 0.1410 & 0.1337 & 0.0307 \\
\hline & 2017 & 0.08 & 1.47 & 0.004 & $221,642.00$ & 0.1390 & 0.1225 & 0.0336 \\
\hline & 2018 & 0.11 & 1.23 & 0.003 & $225,697.00$ & 0.1380 & 0.1225 & 0.0307 \\
\hline \multirow[t]{9}{*}{ BOKF } & 2010 & 0.10 & 1.44 & 0.023 & $23,941.60$ & 0.1620 & 0.4612 & 0.0315 \\
\hline & 2011 & 0.11 & 1.43 & 0.02 & $25,493.90$ & 0.1649 & 0.4661 & 0.0322 \\
\hline & 2012 & 0.12 & 1.33 & 0.014 & $28,148.60$ & 0.1513 & 0.4439 & 0.0299 \\
\hline & 2013 & 0.10 & 1.61 & 0.012 & $27,015.40$ & 0.1556 & 0.4042 & 0.0311 \\
\hline & 2014 & 0.09 & 1.35 & 0.011 & $29,089.70$ & 0.1466 & 0.3448 & 0.0291 \\
\hline & 2015 & 0.09 & 1.38 & 0.014 & $31,476.10$ & 0.1330 & 0.3235 & 0.0285 \\
\hline & 2016 & 0.07 & 1.90 & 0.018 & $32,772.30$ & 0.1281 & 0.2964 & 0.0311 \\
\hline & 2017 & 0.10 & 1.98 & 0.015 & $32,272.20$ & 0.1343 & 0.3143 & 0.0318 \\
\hline & 2018 & 0.11 & 1.25 & 0.011 & $38,020.50$ & 0.1250 & 0.3114 & 0.0270 \\
\hline \multirow[t]{9}{*}{ EWBC } & 2010 & 0.07 & 1.43 & 0.013 & $20,700.50$ & 0.1750 & 0.2034 & 0.0231 \\
\hline & 2011 & 0.11 & 1.32 & 0.01 & $21,968.70$ & 0.1640 & 0.2050 & 0.0198 \\
\hline & 2012 & 0.12 & 1.31 & 0.007 & $22,536.10$ & 0.1610 & 0.1744 & 0.0187 \\
\hline & 2013 & 0.13 & 2.04 & 0.006 & $24,730.10$ & 0.1350 & 0.1468 & 0.0168 \\
\hline & 2014 & 0.13 & 1.95 & 0.005 & $28,743.60$ & 0.1260 & 0.1276 & 0.0185 \\
\hline & 2015 & 0.13 & 1.92 & 0.005 & $32,350.90$ & 0.1220 & 0.1587 & 0.0167 \\
\hline & 2016 & 0.13 & 2.14 & 0.005 & $34,788.00$ & 0.1240 & 0.1499 & 0.0177 \\
\hline & 2017 & 0.14 & 2.29 & 0.004 & $37,121.60$ & 0.1290 & 0.1398 & 0.0178 \\
\hline & 2018 & 0.17 & 1.43 & 0.003 & $41,042.40$ & 0.1370 & 0.1399 & 0.0174 \\
\hline \multirow[t]{9}{*}{ FITB } & 2010 & 0.05 & 1.12 & 0.021 & $111,007.00$ & 0.1814 & 0.1610 & 0.0347 \\
\hline & 2011 & 0.09 & 0.91 & 0.017 & $116,967.00$ & 0.1609 & 0.1556 & 0.0321 \\
\hline & 2012 & 0.12 & 1.01 & 0.012 & $121,894.00$ & 0.1442 & 0.1465 & 0.0335 \\
\hline & 2013 & 0.13 & 1.33 & 0.008 & $130,443.00$ & 0.1408 & 0.1696 & 0.0304 \\
\hline & 2014 & 0.10 & 1.17 & 0.006 & $138,706.00$ & 0.1433 & 0.1864 & 0.0267 \\
\hline & 2015 & 0.11 & 1.09 & 0.005 & $141,048.00$ & 0.1413 & 0.2267 & 0.0268 \\
\hline & 2016 & 0.10 & 1.36 & 0.007 & $142,177.00$ & 0.1502 & 0.2390 & 0.0275 \\
\hline & 2017 & 0.14 & 1.40 & 0.005 & $142,081.00$ & 0.1516 & 0.2477 & 0.0266 \\
\hline & 2018 & 0.14 & 1.02 & 0.004 & $146,069.00$ & 0.1448 & 0.2482 & 0.0269 \\
\hline \multirow[t]{7}{*}{ FHN } & 2010 & $(0.03)$ & 1.30 & 0.042 & $24,699.00$ & 0.1865 & 0.1679 & 0.0543 \\
\hline & 2011 & 0.06 & 0.86 & 0.027 & $24,789.40$ & 0.1789 & 0.1791 & 0.0522 \\
\hline & 2012 & $(0.01)$ & 1.09 & 0.022 & $25,334.00$ & 0.1594 & 0.1892 & 0.0546 \\
\hline & 2013 & 0.01 & 1.31 & 0.025 & $23,789.80$ & 0.1623 & 0.1912 & 0.0483 \\
\hline & 2014 & 0.10 & 1.45 & 0.012 & $25,668.20$ & 0.1618 & 0.1987 & 0.0324 \\
\hline & 2015 & 0.04 & 1.54 & 0.01 & $26,192.60$ & 0.1301 & 0.1952 & 0.0402 \\
\hline & 2016 & 0.10 & 2.02 & 0.008 & $28,555.20$ & 0.1224 & 0.1826 & 0.0324 \\
\hline
\end{tabular}


profitability and value in the post-crisis period

\begin{tabular}{|c|c|c|c|c|c|c|c|c|}
\hline Bank & Year & $\mathrm{ROE}$ & MTBR & NPL & SIZE & TRWCA & LIQ & MAN \\
\hline & 2017 & 0.05 & 1.56 & 0.005 & $41,423.40$ & 0.1110 & 0.1744 & 0.0247 \\
\hline & 2018 & 0.13 & 0.96 & 0.005 & $40,832 \cdot 30$ & 0.1194 & 0.1679 & 0.0299 \\
\hline \multirow[t]{9}{*}{ FMBI } & 2010 & $(0.02)$ & 0.93 & 0.043 & $5,225.40$ & 0.1618 & 0.2250 & 0.0534 \\
\hline & 2011 & 0.03 & 0.78 & 0.038 & $5,141.30$ & 0.1368 & 0.2238 & 0.0509 \\
\hline & 2012 & $(0.02)$ & 1.00 & 0.019 & $4,987.00$ & 0.1190 & 0.2498 & 0.0536 \\
\hline & 2013 & 0.08 & 1.31 & 0.015 & $4,982.10$ & 0.1239 & 0.2490 & 0.0515 \\
\hline & 2014 & 0.07 & 1.21 & 0.011 & $6,062.00$ & 0.1123 & 0.2180 & 0.0468 \\
\hline & 2015 & 0.07 & 1.25 & 0.005 & $6,605.60$ & 0.1102 & 0.2177 & 0.0465 \\
\hline & 2016 & 0.08 & 1.63 & 0.008 & $9,252.80$ & 0.1223 & 0.2261 & 0.0367 \\
\hline & 2017 & 0.06 & 1.32 & 0.007 & $10,408.90$ & 0.1215 & 0.2015 & 0.0400 \\
\hline & 2018 & 0.08 & 1.03 & 0.006 & $12,165.10$ & 0.1262 & 0.2041 & 0.0342 \\
\hline \multirow[t]{9}{*}{ FRC } & 2010 & 0.16 & 1.75 & 0.001 & $22,377.60$ & 0.1461 & 0.1171 & 0.0222 \\
\hline & 2011 & 0.15 & 1.57 & 0.001 & $27,791.80$ & 0.1365 & 0.0487 & 0.0207 \\
\hline & 2012 & 0.14 & 1.48 & 0.002 & $34,389.20$ & 0.1387 & 0.0454 & 0.0197 \\
\hline & 2013 & 0.14 & 2.13 & 0.002 & $42,112.80$ & 0.1389 & 0.0565 & 0.0182 \\
\hline & 2014 & 0.12 & 1.85 & 0.001 & $48,350.20$ & 0.1420 & 0.0457 & 0.0191 \\
\hline & 2015 & 0.11 & 2.05 & 0.002 & $58,981.30$ & 0.1378 & 0.0685 & 0.0186 \\
\hline & 2016 & 0.12 & 2.46 & 0.001 & $73,277.80$ & 0.1446 & 0.0562 & 0.0182 \\
\hline & 2017 & 0.11 & 2.05 & 0.001 & $87,780.50$ & 0.1411 & 0.0537 & 0.0187 \\
\hline & 2018 & 0.11 & 1.85 & 0.001 & $99,205.20$ & 0.1343 & 0.0465 & 0.0193 \\
\hline \multirow[t]{9}{*}{ FULT } & 2010 & 0.07 & 1.09 & 0.027 & $16,275.30$ & 0.1420 & 0.1876 & 0.0251 \\
\hline & 2011 & 0.08 & 0.99 & 0.024 & $16,370.50$ & 0.1520 & 0.1812 & 0.0254 \\
\hline & 2012 & 0.08 & 0.92 & 0.017 & $16,533.10$ & 0.1560 & 0.1797 & 0.0272 \\
\hline & 2013 & 0.08 & 1.22 & 0.012 & $16,934.60$ & 0.1500 & 0.1644 & 0.0272 \\
\hline & 2014 & 0.08 & 1.11 & 0.009 & $17,124.80$ & 0.1470 & 0.1418 & 0.0268 \\
\hline & 2015 & 0.07 & 1.11 & 0.01 & $17,914.70$ & 0.1320 & 0.1443 & 0.0268 \\
\hline & 2016 & 0.08 & 1.54 & 0.009 & $18,944.20$ & 0.1320 & 0.1412 & 0.0258 \\
\hline & 2017 & 0.08 & 1.41 & 0.009 & $20,036.90$ & 0.1300 & 0.1323 & 0.0262 \\
\hline & 2018 & 0.09 & 1.17 & 0.009 & $20,682.20$ & 0.1280 & 0.1049 & 0.0264 \\
\hline \multirow[t]{9}{*}{ PNC } & 2010 & 0.12 & 1.08 & 0.029 & $264,284.00$ & 0.1560 & 0.2625 & 0.0326 \\
\hline & 2011 & 0.10 & 0.94 & 0.022 & $271,205.00$ & 0.1580 & 0.2480 & 0.0336 \\
\hline & 2012 & 0.08 & 0.87 & 0.017 & $305,107.00$ & 0.1470 & 0.2252 & 0.0347 \\
\hline & 2013 & 0.11 & 1.07 & 0.016 & $320,192.00$ & 0.1580 & 0.2105 & 0.0302 \\
\hline & 2014 & 0.10 & 1.18 & 0.012 & $345,072.00$ & 0.1590 & 0.1812 & 0.0275 \\
\hline & 2015 & 0.09 & 1.17 & 0.01 & $358,493.00$ & 0.1470 & 0.1669 & 0.0264 \\
\hline & 2016 & 0.09 & 1.36 & 0.01 & $366,380.00$ & 0.1430 & 0.1774 & 0.0259 \\
\hline & 2017 & 0.12 & 1.57 & 0.008 & $380,768.00$ & 0.1370 & 0.1651 & 0.0273 \\
\hline & 2018 & 0.12 & 1.22 & 0.007 & $382,315.00$ & 0.1300 & 0.1805 & 0.0269 \\
\hline \multirow[t]{9}{*}{ STI } & 2010 & $(0.00)$ & 0.81 & 0.034 & $172,874.00$ & 0.1654 & 0.2003 & 0.0342 \\
\hline & 2011 & 0.03 & 0.48 & 0.023 & $176,859.00$ & 0.1367 & 0.2017 & 0.0352 \\
\hline & 2012 & 0.10 & 0.75 & 0.012 & $173,442.00$ & 0.1348 & 0.1916 & 0.0365 \\
\hline & 2013 & 0.06 & 0.95 & 0.007 & $175,335.00$ & 0.1281 & 0.1737 & 0.0335 \\
\hline & 2014 & 0.08 & 1.01 & 0.005 & $190,328.00$ & 0.1251 & 0.2034 & 0.0291 \\
\hline & 2015 & 0.08 & 0.98 & 0.005 & $190,817.00$ & 0.1254 & 0.1944 & 0.0270 \\
\hline & 2016 & 0.08 & 1.20 & 0.006 & $204,875.00$ & 0.1226 & 0.1994 & 0.0267 \\
\hline & 2017 & 0.10 & 1.34 & 0.005 & $205,962.00$ & 0.1309 & 0.1993 & 0.0280 \\
\hline & 2018 & 0.12 & 1.01 & 0.003 & $215,543.00$ & 0.1202 & 0.1953 & 0.0263 \\
\hline
\end{tabular}


ISSN 2519-4070

\begin{tabular}{|c|c|c|c|c|c|c|c|c|}
\hline Bank & Year & ROE & MTBR & $\overline{N P L}$ & SIZE & TRWCA & LIQ & MAN \\
\hline \multirow[t]{9}{*}{ SNV } & 2010 & $(0.43)$ & 1.01 & 0.046 & $30,093.10$ & 0.1645 & 0.1280 & 0.0335 \\
\hline & 2011 & $(0.06)$ & 0.59 & 0.078 & $27,162.80$ & 0.1649 & 0.1553 & 0.0333 \\
\hline & 2012 & 0.34 & 0.74 & 0.028 & $26,760.00$ & 0.1618 & 0.1348 & 0.0305 \\
\hline & 2013 & 0.04 & 1.24 & 0.021 & $26,201.60$ & 0.1300 & 0.1403 & 0.0283 \\
\hline & 2014 & 0.06 & 1.26 & 0.009 & $27,050.20$ & 0.1275 & 0.1309 & 0.0275 \\
\hline & 2015 & 0.07 & 1.46 & 0.007 & $28,792.70$ & 0.1270 & 0.1375 & 0.0249 \\
\hline & 2016 & 0.08 & 1.80 & 0.006 & $30,104.00$ & 0.1201 & 0.1369 & 0.0251 \\
\hline & 2017 & 0.09 & 2.01 & 0.005 & $31,221.80$ & 0.1223 & 0.1406 & 0.0263 \\
\hline & 2018 & 0.15 & 1.32 & 0.004 & $32,669.20$ & 0.1237 & 0.1365 & 0.0254 \\
\hline \multirow[t]{9}{*}{ UMB } & 2010 & 0.09 & 1.58 & 0.003 & $12,404.90$ & 0.1245 & 0.4846 & 0.0413 \\
\hline & 2011 & 0.09 & 1.26 & 0.005 & $13,541.40$ & 0.1220 & 0.4883 & 0.0416 \\
\hline & 2012 & 0.10 & 1.38 & 0.005 & $14,927.20$ & 0.1192 & 0.5132 & 0.0396 \\
\hline & 2013 & 0.10 & 1.93 & 0.005 & $16,911.90$ & 0.1443 & 0.4324 & 0.0369 \\
\hline & 2014 & 0.08 & 1.58 & 0.004 & $17,501.00$ & 0.1404 & 0.4219 & 0.0381 \\
\hline & 2015 & 0.07 & 1.21 & 0.006 & $19,094.20$ & 0.1280 & 0.3855 & 0.0369 \\
\hline & 2016 & 0.08 & 1.95 & 0.007 & $20,682.50$ & 0.1282 & 0.3383 & 0.0322 \\
\hline & 2017 & 0.12 & 1.64 & 0.005 & $21,771.60$ & 0.1404 & 0.3110 & 0.0324 \\
\hline & 2018 & 0.09 & 1.34 & 0.004 & $23,351.10$ & 0.1395 & 0.3104 & 0.0307 \\
\hline \multirow[t]{9}{*}{ USB } & 2010 & 0.13 & 1.88 & 0.02 & $307,786.00$ & 0.1330 & 0.2095 & 0.0305 \\
\hline & 2011 & 0.16 & 1.65 & 0.014 & $340,122.00$ & 0.1330 & 0.1890 & 0.0291 \\
\hline & 2012 & 0.16 & 1.74 & 0.009 & $353,855.00$ & 0.1310 & 0.1328 & 0.0295 \\
\hline & 2013 & 0.16 & 2.03 & 0.007 & $364,021.00$ & 0.1320 & 0.1352 & 0.0282 \\
\hline & 2014 & 0.15 & 2.08 & 0.006 & $402,529.00$ & 0.1360 & 0.1658 & 0.0266 \\
\hline & 2015 & 0.14 & 1.84 & 0.005 & $421,853.00$ & 0.1330 & 0.1734 & 0.0259 \\
\hline & 2016 & 0.14 & 2.09 & 0.005 & $445,964.00$ & 0.1320 & 0.1838 & 0.0258 \\
\hline & 2017 & 0.14 & 2.04 & 0.004 & $462,040.00$ & 0.1290 & 0.1847 & 0.0277 \\
\hline & 2018 & 0.15 & 1.64 & 0.003 & $467,374.00$ & 0.1260 & 0.1834 & 0.0267 \\
\hline \multirow[t]{9}{*}{ WBS } & 2010 & 0.03 & 0.98 & 0.025 & $17,981.70$ & 0.1390 & 0.1438 & 0.0300 \\
\hline & 2011 & 0.08 & 0.98 & 0.017 & $18,714.30$ & 0.1460 & 0.1641 & 0.0273 \\
\hline & 2012 & 0.09 & 0.90 & 0.016 & $20,146.80$ & 0.1370 & 0.1682 & 0.0249 \\
\hline & 2013 & 0.08 & 1.36 & 0.013 & $20,853.00$ & 0.1420 & 0.1597 & 0.0239 \\
\hline & 2014 & 0.09 & 1.35 & 0.009 & $22,533.20$ & 0.1410 & 0.1356 & 0.0223 \\
\hline & 2015 & 0.09 & 2.17 & 0.009 & $24,641.10$ & 0.1291 & 0.1292 & 0.0225 \\
\hline & 2016 & 0.08 & 2.07 & 0.008 & $26,072.50$ & 0.1267 & 0.1220 & 0.0239 \\
\hline & 2017 & 0.10 & 2.03 & 0.007 & $26,487.60$ & 0.1340 & 0.1083 & 0.0250 \\
\hline & 2018 & 0.13 & 1.66 & 0.008 & $27,610.30$ & 0.1363 & 0.1144 & 0.0256 \\
\hline \multirow[t]{9}{*}{ WASH } & 2010 & 0.0918 & 1.32 & 0.0096 & $2,909.50$ & 0.1279 & 0.234 & 0.029 \\
\hline & 2011 & 0.1076 & 1.38 & 0.0098 & $3,064.10$ & 0.1286 & 0.203 & 0.030 \\
\hline & 2012 & 0.1216 & 1.46 & 0.0096 & $3,071.90$ & 0.1326 & 0.146 & 0.033 \\
\hline & 2013 & 0.1156 & 1.88 & 0.0074 & $3,188.90$ & 0.1329 & 0.149 & 0.031 \\
\hline & 2014 & 0.1212 & 1.94 & 0.0055 & $3,586.90$ & 0.1256 & 0.121 & 0.027 \\
\hline & 2015 & 0.1208 & 1.79 & 0.0069 & $3,771.60$ & 0.1258 & 0.124 & 0.026 \\
\hline & 2016 & 0.1211 & 2.46 & 0.0068 & $4,381.10$ & 0.1258 & 0.193 & 0.023 \\
\hline & 2017 & 0.114 & 2.22 & 0.0045 & $4,529.90$ & 0.1245 & 0.190 & 0.023 \\
\hline & 2018 & 0.1585 & 1.83 & 0.0032 & $5,010.80$ & 0.1256 & 0.203 & 0.021 \\
\hline
\end{tabular}

Source: Bloomberg. (2019). Bloomberg Professional [Online] Available at: Subscription Service (Assessed: 21 August 2019) 


\section{References}

Arellano, M., \& Bond, S. (1991). Some tests of specification for panel data: Monte Carlo evidence and an application to employment equations. The Review of Economic Studies, 58(2), 277-297. http://www.jstor.org/stable/ 2297968

Ali, M., \& Puah, C. (2019). The internal determinants of bank profitability and stability: An insight from banking sector of Pakistan. Management Research Review, 42(1), 49-67.

BIS. (2018). History of the Basel Committee. Bank for International Settlement. https://www.bis.org/bcbs/history.htm

Bivens, J., \& Wething, H. (2013). A progressive growth strategy for the USA. FES. https://library.fes.de/pdf-files/id/ipa/10287.pdf

Bloomberg. (2019). Bloomberg Professional [Online] Available at: Subscription Service (Assessed: 21 August 2019)

Board of Governors of the Federal Reserve System. (2018). Financial Stability Report. The Federal Reserve System. https://www.federalreserve.gov/ publications/files/financial-stability-report-201811.pdf

Board of Governors of the Federal Reserve System. (2019). Supervision and Regulation Report. The Federal Reserve System. https://www.federalreserve.gov/ publications/files/201811-supervision-and-regulation-report.pdf

Bolt, W., de Haan, L., Hoeberichts, M., van Oordt, M., \& Swank, J. (2012). Bank profitability during recessions. Journal of Banking \& Finance, 36, 25522564.

Bourke, P. (1989). Concentration and other determinants of bank profitability in Europe, North America and Australia. Journal of Banking and Finance, 13, 65-79.

Bouzgarrou, H., Jouida, S. L, \& Louhichi, W. (2018). Bank profitability during and before the financial crisis: Domestic versus foreign banks. Research in International Business and Finance, 44, 26-39.

Chronopoulos, D., Liu, H., McMillan, F., \& Wilson, J. (2015). The dynamics of US bank profitability. The European Journal of Finance, 21(5), 427-443.

Cucinelli, D. (2015). The impact of non-performing loans on bank lending behavior: Evidence from the Italian banking sector. Eurasian Journal of Business and Economics, 8(6), 59-71. 
Federal Reserve Board. (n.d.). Structure of the Federal Reserve System. http://www.federalreserve.gov

Gasbarro, D., Sadguna, I., \& Zumwalt, J. (2002). The changing relationship between CAMEL ratings and bank soundness during the Indonesian banking crisis. Review of Quantitative Finance and Accounting, 19, 247-260.

Ghosh, A. (2017). Impact of non-performing loans on US product and labor markets. Journal of Financial Economic Policy, 9(3), 302-323.

Gugler, K., \& Peev, E. (2018). The persistence of profits in banking: An international comparison. Applied Economics, 50(55), 5996-6009.

Hoffmann, P. (2011). Determinants of the profitability of the US banking industry. International Journal of Business and Social Science, 2(22), 255-269. http://www.ijbssnet.com/journals/Vol_2_No_22_December_2011/30.pdf

Ishak, I., Ismail, N., Razali, N.A., Bakar, R., \& Ramlan, H. (2016). Credit risk management and profitability of banks listed on Bursa Malaysia. International Symposium \& Exhibition on Business and Accounting.

Kasavica, P., \& Jovic, Z. (2015). Impact of asset quality on bank profitability case study. Industrija, 43(4), 105-128.

Liu, D-Y., Wu, Y-C., Lin, C-H., \& Lu, W-M. (2017). The effects of nonperforming loans on dynamic network bank performance. Discrete Dynamics in Nature and Society, 2017, 9458315. https://doi.org/10.1155/2017/9458315

Reddy, D.M., \& Prasad, K.V.N. (2011). Evaluating performance of regional rural banks: An application of Camel model. Journal of Arts, Science \& Commerce, 2(4), 61-67.

Saeed, M.S., \& Zahid, N. (2016). The impact of credit risk on profitability of the commercial banks. Journal of Business and Financial Affairs, 5(2), 1-7.

Sargan, J. D. (1988) [1975]. «Testing for misspecification after estimating using instrumental variables». Contributions to Econometrics. New York: Cambridge University Press.

Terraza, V. (2011). The effect of bank size on risk ratios: Implications of banks' performance. Procedia Economics and Finance, 30(2015), 903-909.

Tran, V., Lin, C-T., \& Nguyen, H. (2016). Liquidity creation, regulatory capital, and bank profitability. International Review of Financial Analysis, 48, 98-109. 